\title{
STRATEGY FOR INVESTIGATION OF FILTER MATERIAL FOR WASTEWATER TREATMENT
}

\author{
Britt-Marie Svensson ${ }^{1}$ \\ Lennart Mårtensson \\ Kristianstad University, Sweden \\ Lennart Mathiasson \\ Lund University, Sweden
}

\begin{abstract}
This paper presents a strategy for an investigation to give a comprehensive picture of a biological filter aimed for treatment of different kinds of wastewaters, such as landfill leachate, stormwater and wastewater from vehicle washes. The strategy is based on batch equilibrium experiments and includes three main parts. Under focus is the ability of the filter material to simultaneously remove organic and inorganic pollutants from wastewater, as well as the environmental impact of using materials that would normally be waste to build filters, on one hand, and of disposing of used filter material on the other. The filter material used in these tests is naturally occurring materials such as peat and residual products such as carboncontaining ash. A filter material in a treatment system needs eventually to be exchanged either because it has been saturated by pollutants or because the hydraulic conductivity has decreased too much. After usage the filter material is considered solid waste and is to be classified and handled according to that. Several possible alternatives for further handling, i.e. landfilling, combustion or composting can be selected. A characterization of filter material used for three years in a full-scale filter system for landfill leachate treatment has revealed that energy recovery at an incineration plant could be a possible handling alternative for the used filter material.
\end{abstract}

\section{KEYWORDS}

Batch test, leaching test, peat, carbon-containing ash, wastewater treatment, solid waste

\section{INTRODUCTION}

There are large needs in the world for treatment of different types of wastewater. Especially leachate water from landfills with their large concentrations of variety of pollutants including heavy metals and organic pollutants as phenols is a world wide problem. Since large wastewater volumes must be treated there is a need of low cost systems, which especially in developing countries preferably should be based on low-tech solutions. In these two respects natural systems with retention ponds followed by soil-plant irrigation system, or filter based system (with a low-cost filter material) combined with a retention pond, are two attractive ways of wastewater treatment. 
As indicated by the discussion above it is essential for a filter based material that it is cheap but still fulfills its purpose of removing dangerous pollutants from the considered wastewater.

The objective of this study has been to present a new strategy based on laboratory batch equilibrium tests for evaluation of adsorbent candidates aimed for treatment of different kinds of wastewaters, such as landfill leachate, stormwater and wastewater from vehicle washes.

The material chosen to be tested, a mixture of peat and carbon-containing ash, has been evaluated not only with respect to its primary goal, namely to simultaneously remove both organic and inorganic pollutants, but also with respect to its overall environmental friendliness. The latter aspect includes leakage tests of new filter material and filter material, which has been used for so long that it needs to be displaced due to saturation or clogging. The aspect of environmental friendliness includes also methodology for handling the disposed material. This paper will present a general approach to get a comprehensive picture of the properties of a tested filter.

\section{EXPERIMENTAL}

A flow chart of the strategy for an investigation to give a comprehensive picture of a biological filter is shown in Figure 1. The strategy includes three main parts: characterization of a filter-material (both the mixture of peat and carbon-containing ash (Peat + Ash) as well as its components separately, (Peat) and (Ash)); investigation of the removal efficiency of the mixture; and characterization of the filter mixture after long-term usage. 


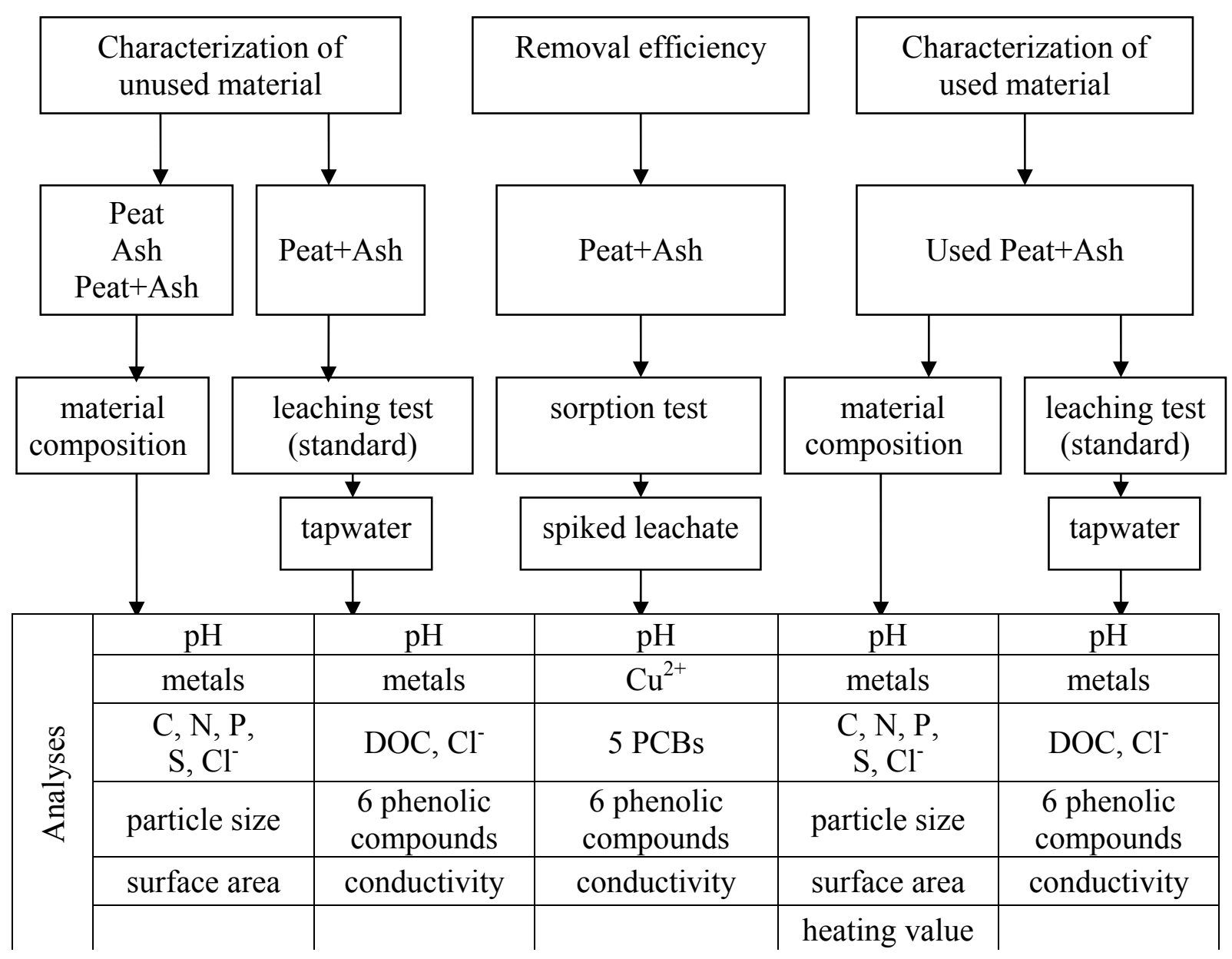

Figure 1. An outline of the strategy based on the batch equilibrium test, for evaluation of the suitability of an adsorbent for filter-based treatment of wastewater.

\subsection{Characterization of unused filter materials}

Characterization of filter materials included determination of material composition and a leaching test. Determination of the composition of the unused Peat+Ash as well as its components (Peat) and (Ash), included determination of the dry weight (dw) according to SS 028113 [1], measuring loss of ignition according to SS 027105 [2] and measuring the particle size according to SS 027123 [3]. Surface area was determined according to Carter $e t$ al. [4] at the laboratory of the Institute of Agricultural and Environmental Sciences, Department of Soil Science and Agrochemistry, Estonian University of Life Sciences, Estonia. The leaching test of unused Peat+Ash was performed according to SS-EN 12457-4 [5]. Dissolved organic carbon (DOC) in the eluates from the leaching test, as well as metal concentrations in the solid materials and in the eluates, were determined at a reference laboratory (Section for Plant Ecology and Systematics, Department of Ecology, Lund University, Sweden). Chloride ion concentrations in the eluates were analysed according to the standard method SS-EN 10304-2 [6] using liquid chromatography (LC) with an anion exchange column. Six phenolic compounds (phenol, p-creosol, o-creosol, 4-chlorophenol, 2,4-dimethylphenol, 4-chloro-3-methylphenol) were determined using high performance liquid chromatography equipment with a diode array detector (HPLC-DAD) according to Bergström et al. [7]. 


\subsection{Removal efficiency of different pollutants}

The simultaneous trapping process of some typical pollutants used as markers, $\mathrm{Cu}$, polar phenolic compounds and non-polar polychlorinated biphenyls (PCBs) was investigated. Dried filter material $(4 \mathrm{~g})$ was placed into 2-litre polypropylene bottles and one litre of spiked leachate solution was added. The bottles were agitated on a shaking table at $110 \mathrm{rpm}$ for 24 hours at room temperature. After shaking the samples were filtrated. Values of conductivity, $\mathrm{pH}$ and concentrations of phenolic compounds, before and after each test, were obtained. Copper was analysed according to SS $02 \quad 8150$ [8] using an atomic absorption spectrophotometer (AAS), and PCBs were enriched according to Thörneby et al. [9] and analysed using a gas chromatograph equipped with a mass spectrometer (GC-MS) from Thermo Quest, UK, as described by Hallgren et al. [10].

\subsection{Characterization of the filter material after long-term usage}

Characterization of the mixture that had served as the filter material for treatment of leachate from an industrial landfill over three years included the same steps as in the characterization of unused mixture (Figure 1). Accordingly, the experimental procedures, measurements and analyses were the same as described in section 2.1. A comparison of pollutant concentrations obtained from the leaching test and the limit values proposed in Swedish waste acceptance criteria [11] was carried out in order to judge in what classification the used filter material would leakage concentrations of pollutants. Additionally, an effective heating value was determined on the used Peat + Ash at a commercial laboratory (Analycen, Lidköping, Sweden), to investigate whether the energy content of the used material could be recovered at an incineration plant.

\section{RESULT AND DISCUSSION}

The present study has shown that relevant information about removal efficiencies of metals and non-polar, persistent organic pollutants (POPs) such as PCBs can be achieved in a batch test at neutral or slight basic $\mathrm{pH}$, which is the expected $\mathrm{pH}$ in many landfill leachates. However, the removal of polar organic phenolic compounds occurred with only limited efficiency. The results obtained from this type of batch experiment for polar, more easily biodegradable compounds may be misleading, since only physico-chemical processes are used to remove pollutants from the aqueous phase. With the limited time used in a batch experiment (usually hours) it is not likely that microbiological degradation processes will have occurred. For degradation of phenolic compounds from wastewaters, the establishment of a microbiological environment consisting of both fungi and bacteria is required [12]. Previous long-term studies on the actual mixture in column [13] and pilot plant experiments [14] demonstrate that very high reductions (often about 95\%) of different phenolic compounds can in fact be achieved. In these studies the establishment of phenol-degrading bacteria communities has been shown to accomplish this reduction. It is thus obvious that, for polar organic compounds which more easily are degraded by bacterial activity or oxidation processes, complimentary measurements are needed.

When a filter material needs to be exchanged, either because it has been over-saturated by pollutants or because the hydraulic conductivity has decreased too much, possible alternatives for handling the material can be selected. After usage the filter material is considered solid waste and is to be classified and handled according to that. Several possible alternatives for further handling, i.e. landfilling, combustion or composting may be selected. For the studied filter material, all average values of analyzed parameters were clearly below the leakage proposed limit values for non-hazardous waste, except for DOC. From this point of view an 
incineration process, eliminating the DOC problem, seems to be a good alternative. Furthermore, the concentrations of most metals in used Peat+Ash are similar to values usually found in peat in Swedish environment [15] and should thus not become a problem when incinerated. Also the effective heating value for used Peat+Ash is suitable for deriving useful energy from incineration. Co-combustion of peat in fuel blends is often used in heat and power plants [16], and peat used for remediation of diesel-oil-contaminated soil has also shown to be useful as an energy source [17]. For all types of filter with large content of organics, heating values should be obtained so the favourable approach of incineration always will be considered.

The study reported in this paper was restricted to a mixture of peat and carbon-containing ash, but the described strategy should be suitable for testing other filter materials as well. Furthermore, the study was performed on a filter used in a full-scale filter system for landfill leachate treatment, but a mixture of peat and carbon-containing ash may be used for other wastewater treatment systems. This study has shown that it is possible to design a filter with ability to simultaneously remove organic and inorganic pollutants from wastewater. By include waste material in the filter material, the cost of the filter decreases markedly and besides the life cycle of the waste material is extended, which is environmentally favourably.

\section{REFERENCES}

[1] SIS, 1981, Determination of dry matter and ignition residue in water, sludge and sediment. Swedish standards institute, SIS Förlag AB, 11880 Stockholm, Sweden. SS 0281 13. (in Swedish)

[2] SIS, 1990, Geotechnical tests - organic content in soil - ignitionloss method. Swedish Standards Institute, SIS Förlag AB, 11880 Stockholm, Sweden. SS 0271 05. (in Swedish)

[3] SIS, 1992, Geotechnical tests -Particle size distribution - Sieving. Swedish Standards Institute, SIS Förlag AB, 11880 Stockholm, Sweden. SS 0271 23. (in Swedish)

[4] Carter, D.L., M.M. Mortland, and W.D. Kemper, Specific Surface, in Methods of Soil Analysis, Part 1: Physical and Mineralogical Methods (Agronomy, No 9), A. Klute, Editor. 1986, Amer. Society of Agronomy, 2nd edition: Madison, USA.

[5] SIS, 2003, Characterisation of waste - Leaching - Compliance test for leaching of granular waste materials and sludges - Part 4. Swedish Standards Institute, SIS Förlag AB, 11880 Stockholm, Sweden. SS-EN 12457-4. (in Swedish)

[6] SIS, 1996, Water qualities - Determination of dissolved anions by liquid chromatography of ions - Part 2 Swedish Standards Institute, SIS Förlag AB, 11880 Stockholm, Sweden. SSEN ISO 10304-2. (in Swedish)

[7] Bergström, S., et al., 2007. Development and application of an analytical protocol for evaluation of treatment processes for landfill leachates. I. Development of an analytical protocol for handling organic compounds in complex leachate samples. International Journal of Environmental Analytical Chemistry, 87(1): p. 1-15.

[8] SIS, 1993, Water analyses- Atomabsorptionsspectrophotometri in flame - Speciella anvisningar för aluminuim, lead, iron, cadmium, cobalt, copper, krom, mangan, nickel and zinc. Swedish standards institute, SIS Förlag AB, 11880 Stockholm, Sweden. SS 028152. (in Swedish)

[9] Thörneby, L., et al., 2006. The performance of a natural treatment system for landfill leachate with special emphasis on the fate of organic pollutants. Waste Management and Research, 24: p. 183-194.

[10] Hallgren, P., et al., 2006. Measuring bioavailability of polychlorinated biphenyls in soil to earthworms using selective supercritical fluid extraction Chemosphere, 63: p. 1532-1538. 
[11] Swedish EPA, 2004, Naturvårdsverkets föreskrifter om deponering, kriterier och förfaranden för mottagning av avfall vid anläggningar för deponering avfall. Swedish Environmental Protection Agency. NFS 2004:10. (in Swedish)

[12] Perron, N. and U. Welander, 2004. Degradation of phenol and cresole at low temperatures using a suspended-carrier biofilm process. Chemosphere, 55: p. 45-50.

[13] Kängsepp, P., et al., 2008. Column studies aiming at identification of suitable filter materials for pollutant removal from landfill leachate. International Journal of Environment and Waste Management, 2(6): p. 506-525.

[14] Kängsepp, P., L. Mathiasson, and L. Mårtensson, 2010. Filter-based treatment of leachate from an industrial landfill containing shredder residues of end-of-life vehicles and white goods. Waste Management, 30(2): p. 236-245.

[15] SGU. 2010. Torv - kemisk sammansättning. http://www.sgu.se/sgu/sv/samhalle/energiklimat/torv/torv-kemi.html. [downloaded 2010-10-10]; (in Swedish)

[16] Burvall, J. and M. Öhman, 2006, Samförbränning av torv och biobränslen askrelaterade systemfördelar. Statens energimyndighet. (in Swedish)

[17] Ghaly, R.A., et al., 1999. Remediation of diesel-oil-contaminated soil using peat. Energy Sources, 21(9): p. 785-799. 